\title{
MAGYARORSZÁG ÉS AZ EURÓPAI UNIÓ KÖZLEKEDÉSI HÁLÓZATÁNAK FEJLESZTÉSE ÉS ANNAK LOGISZTIKAI HATÁSA
}

Development of the transport network of Hungary and the European Union and its impact on logistics

\section{Szalánczi-Orbán Virág ${ }^{1}$}

\begin{abstract}
Absztrakt: A közlekedési hálózat meghatározó jelentőséggel bír a gazdaságban: nemcsak kritikus infrastruktúra, hanem a gazdaságot átalakító erő is egyben. A meglévő rendszerek és hálózatok azonban az új kihívásoknak nem mindenben feleltek meg, ezért egységes és felzárkóztató fejlesztésre volt szükség. A közlekedési hálózatok jelenlegi fejlesztései, az Európai Unió által támogatott projektek megvalósulása és elképzelései több lehetőséget és iránymutatást kínálnak. Ebben a tanulmányban elsősorban a logisztikai vonzatokat vizsgálom. A hazai és uniós hálózatfejlesztés mellett a logisztikai lehetőségek figyelembevételével a regionális erők szerepét, valamint a globális hatásokat is egyidejûleg kívánom bemutatni.
\end{abstract}

Kulcsszavak: Közlekedési hálózat, TEN-T, CEF, Új Selyemút

\begin{abstract}
The transport network is of decisive importance to the economy, not only as a critical infrastructure, but also as a transformative force in the economy. However, existing systems and networks do not fully address the new challenges, and a unified and catching-up development was needed. Current development plans and ideas of the current developers of transport networks, supporters of the European Union, provide various guidelines. This study focuses primarily on the logistics aspects. In addition to domestic and EU network development, I also examine the role of regional forces and global impacts, with logistical options in mind.
\end{abstract}

Keywords: Transport network, TEN-T, CEF, New Silk Road

1 A szerzőről: Az Óbudai Egyetem Biztonságtudományi Doktori Iskola hallgatója. Elérhetősége: szalancziorban.virag@phd.uni-obuda.hu 


\section{BEVEZETÉS}

Magyarország és az Európai Unió közlekedés hálózata, logisztikai kapcsolódása, az ismert és használt útvonalhálózatok folyamatos jelleggel történő átalakulása egy dinamikusan fejlődő terület. A korábban ismert és használt szokások formálódnak, a folyosók és tranzitútvonalak változnak, új lehetőségek, új hálózatok és új irányelvek alakítják a közlekedési hálózatokat. Ezek a látható és tervezett irányok számos területen okoznak változást, így a logisztikában is. Ahhoz, hogy megértsük és prognosztizálhassuk a jövőbeli lehetőségeket és kihívásokat, kutatnunk kell a múlt állapotait, ezt főleg a meglévő adatok feldolgozásával, elemzések és riportok áttekintésével és felhasználásával, térképes és grafikus ábrák összehasonlításával kívánom elérni. Esettanulmányom célja rávilágítani a fejlesztésben rejlő logisztikai kapcsolódási pontokra és lehetőségekre, Európában és globális szinten is. Mindezek eléréséhez átfogó képet kell látnunk arról, hogy honnan hova tart ez a terület, a közlekedési hálózat áttekintését, az aktuálisan futó projekteken és azok megvalósításán át, a jövőbeli lehetőségekig vizsgálva.

\section{AZ EURÓPAI UNIÓ KÖZLEKEDÉSI HÁLÓZATA (TEN-T)}

A közlekedés egy stratégiai ágazat, egy úgynevezett kritikus infrastruktúra. Jelentős hatása van nemcsak a társadalomra, hanem a gazdaságra is, jóformán mindenkit érint. A közlekedés és ágazatai hozzájárulnak a növekedéshez, a globális versenyképesség növeléséhez, az Unión belüli mozgáshoz. A közlekedési hálózatok rendszerének fontos szerepe van az egységes piac fenntartásában. A rendszer célja, a hatékony, biztonságos, egységes és környezetbarát hálózat megléte. Az infrastruktúrát érintő beruházások erôsítik az Európai Unió gazdaságát és kohézióját. ${ }^{2}$

Amennyiben az áruszállítási volumeneket vesszük figyelembe, úgy láthatjuk, hogy a világ áruszállításának jelentős része a tengerekről, vízi közlekedéssel érkezik Európába, a kereskedelem 74 \%-át teszi ki ez az beérkezési mód. A világ 15 legnagyobb forgalmát bonyolító kikötője közül 3 Európában van (Rotterdam, Hamburg, Antwerpen). Ennek a folyamatosan növekvő volumennek a további, elsősorban szárazföldön történő

2 Delivering TEN-T RePORT, 2017. 
továbbítása jelenti a kihívást. ${ }^{3}$ A szárazföldi továbbítás rendszerét és hálózatát láthatjuk az 1. számú ábrán.

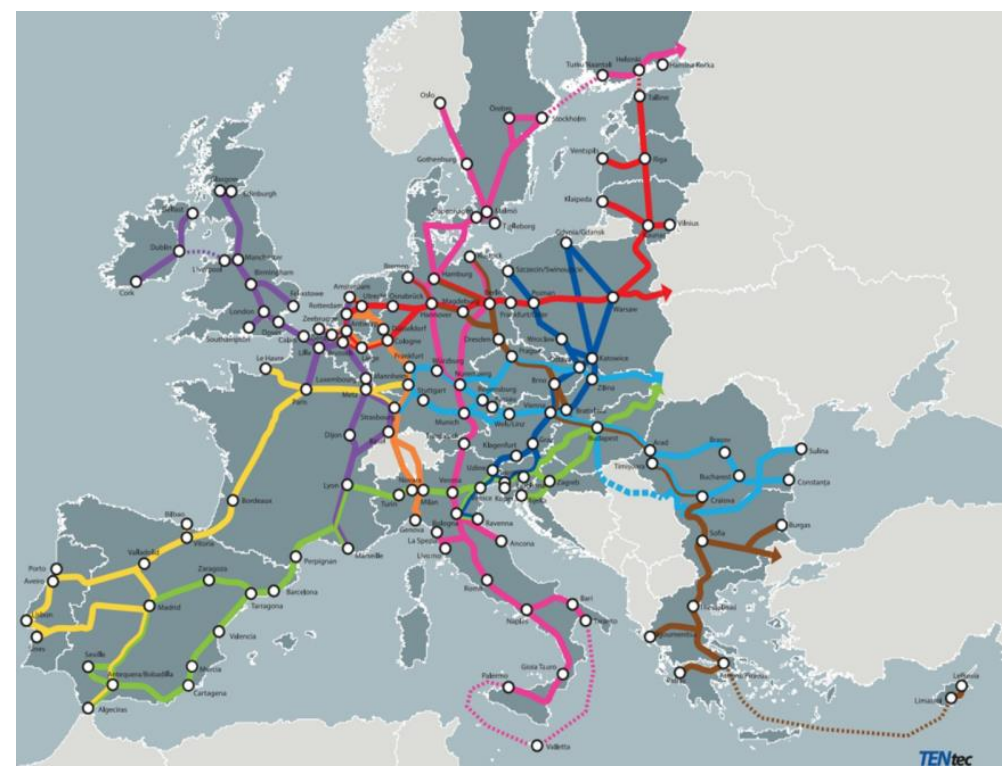

1. számú ábra: Európai korridorok. ${ }^{4}$

A transzeurópai közlekedési hálózatok és korridorok rendszere és kapcsolódási pontjai jól kivehetőek az ábrán. Ezen fő útvonalak a gazdaság és kereskedelem egyik legjobb mozgatói, amelyek a következőek:

- Balti-Adria folyosó

- Északi-tenger. Balti folyosó

- Földközi-tengeri folyosó

- Keleti/Kelet-mediterrán folyosó

- Skandináv-mediterrán folyosó

- Rajna-alpesi folyosó

- Atlanti folyosó

- Az Északi-tenger mediterrán folyosó

- Rajna-Duna folyosó. ${ }^{5}$

${ }^{3}$ EUROPEAN PORTS REPORT, 2015.

${ }^{4}$ European CORRIDORS MAP, 2015.

5 The Core NetWork CORRIDORS REPORT, 2013. 


\section{MAGYARORSZÁG KÖZLEKEDÉSI HÁLÓZATA ÉS KAPCSOLÓDÁSA A TEN-T HÁLÓZATHOZ}

Magyarország földrajzi adottságai által jól kapcsolódik az transzeurópai közlekedési hálózathoz, számos korridor halad át az országon (TEN, Páneurópai Korridorok, TINA). ${ }^{6}$

A páneurópai és TEN folyosók Magyarországot érintô szakaszai:

- IV. Drezda/Nürnberg-Prága-Brno-Pozsony-Győr-Budapest-AradCraiova-Szófia-Isztambul;

- V. Velence-Trieszt/Fiume-Ljubljana-Maribor-Budapest-UngvárLviv-Kijev;

- V/b Fiume-Zágráb-Budapest;

- V/c Ploče-Szarajevó-Eszék-Budapest;

- VII. Elérhetô az Északi-tenger a Rajna-Majna-Duna-csatornán keresztül;

- X/b Budapest-Újvidék-Belgrád. ${ }^{7}$

A hazánkat átívelő közlekedési hálózatok nagy jelentőséggel bírnak hazánk logisztikai szerepének megitélésének és lehetőségeinek szempontjából, hiszen koncentráltan vannak jelen. A hazai kiépítettség és áruszállítási kapcsolatok, a logisztikai szolgáltatók helyzete, a kialakult dinamikák és kombinált szállítási módok is élvezik az ezen korridorok helyzetéből fakadó előnyöket (2. számú ábra).

\footnotetext{
${ }^{6}$ FLEISCHER, 2007.

${ }^{7}$ FLEISCHER, 2007.
} 


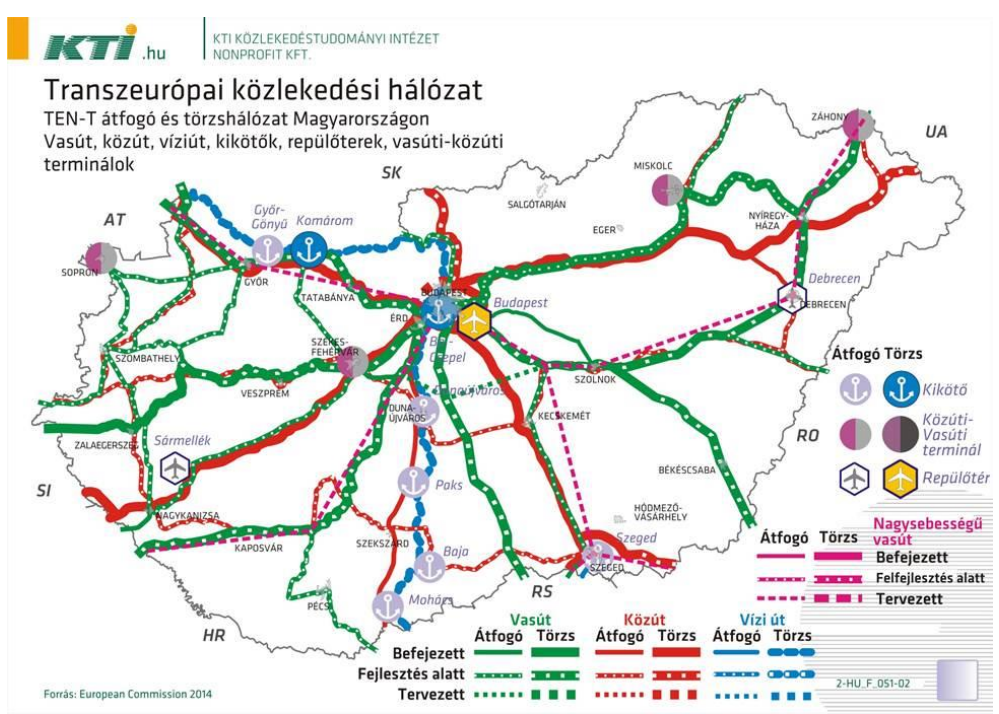

2. számú ábra: Transzeurópai közlekedési hálózat átfogó és törzshálózat, terminálok. ${ }^{8}$

\section{A KÖZLEKEDÉSI HÁLÓZAT FEJLESZTÉSÉNEK IRÁNYVONALAI (CEF)}

Az Európai Unió közlekedési helyzete, a közlekedésfejlesztés kérdése, az összekapcsolt rendszerekben való gondolkodás és a technológia fejlődése, az igények változása és a gazdasági teljesítmények javítás érdekében, az Európai Biztosság 2014-ben felkérte a tagállamokat, hogy javaslatot tegyenek a közlekedési kapcsolatok javítására. A korábbi infrastruktúra sok eleme fejlesztésre szorul. Az új utak és hálózatok kialakulása, az árusszállítási útvonalak akár radikális változtatása javíthatja a gazdasági teljesítményt, elérhetôvé válhat egy biztonságos, versenyképes és digitális európai közlekedési rendszer. Az Európai Hálózatfinanszírozási Eszköz (CEF) közlekedésre vonatkozó projektje által elérhető finanszírozás többszörösére nőtt a 2014-2020-as periódusban. A projekt a közlekedés, az energia és a távközlési szektor fejlesztésére koncentrál. Az első körben elérni kívánt céloknak 2030-ig kell megfelelni. Cél a tagállamok rendszereinek és erőforrásainak jobb kihasználása, a teljesítmények növelése, ágazatok közötti

${ }^{8}$ KÖZLEKEDÉSTUdOMÁNYI INTÉZET, 2014. 
szinergia elérése, közlekedés digitalizálása, fentarthatóság elérése, új törzshálózatok kialakítása, technológia és technikai fejlesztések, egységesebb, összpontosított hálózat elérése. A főbb iránymutatások a következők:

- 94 fő európai kikötő vasúti és közúti összeköttetéssel;

- 38 kulcs repülőtér vasúti összeköttetésekkel a nagyvárosokkal;

- 15.000 kilométernyi vasutat korszerúsítése nagysebességűvé;

- 35 határon átnyúló projektek a szűk keresztmetszetek csökkentésére. ${ }^{9}$

A 2014-2020-as ciklus végéhez közeledve számos projekt valósult meg vagy van folyamatban. A teljes CEF közlekedésre szánt finanszírozást olyan tevékenységekbe fektetik be, amelyek közvetlenül hozzájárulnak a törzshálózat fejlesztéséhez (kb. 88-90\%) és az átfogó hálózat fejlesztéséhez, további befektetések valósultak meg a mobil eszközökben, a mozdonyokban (beleértve az ERTMS-et), hajók és más tevékenységekben. A finanszírozás nagy részét a Rajna-Duna folyosó kapta (18-20\%). Valamint kiemelt terület lett a vasúti közlekedés modernizálása, ahol ugyancsak több projekt valósult meg. A CEF projektek integrálják a közlekedési módokat, hozzájárultak az új összekötések létrejöttéhez, elősegítik a környezetbarát közlekedés elérését. A CEF projektek a közlekedésre vonatkozó fejlesztések finanszírozásával összhangban az energia és távközlési rend-szerek és hálózatok fejlesztésével kapcsolatos projekteket is támogatja. E három terület (közlekedés, energia, távközlés) közös fejlesztése a következő időszakban is várhatóan jelentős támogatásban részesülhet. A felzárkóztatás, az egységes rendszerek kialakítása továbbra is folytatódni fog, a biztonságos és környezetbarát rendszerek elérése továbbra is kiemelt cél. Figyelembe véve a fejlesztési javaslatokat, új, többéves pénzügyi keret kialakítása a cél. ${ }^{10}$

\section{MAGYARORSZÁG KÖZLEKEDÉSI FEJLESZTÉSI LEHETŐSÉGEI, IRÁNYVONALAI AZ ÁRUSZÁLLIITÁS FIGYELEMBEVÉTELÉVEL}

Hazánkban is több CEF projekt valósult meg az elmúlt években, mind a vasúti fejlesztések, mind a közúthálózat fejlesztése terén. A már létrejött vízi és légi közlekedés fejlesztésére elnyert támogatások hatására a versenyképesség nôtt. Az Európai Unió által meghatározott irányvonalak és

\footnotetext{
${ }^{9}$ EUROPEAN COMMISSION-CORRIDORS, REPORT, 2014.

${ }^{10}$ European COMMission, REPORT, 2019.
} 
fejlesztési tervek értelmében a következő periódusokban is komolyabb fejlesztési lehetőségek lesznek adottak. Amennyiben az áruszállítási volumeneket vesszük figyelembe úgy az alábbi (3. számú ábra) prognózist elemezhetjük:

Rㅍㄴ. hu

TRENDEK 2050-ig - Magyar áruszállítási teljesítmények
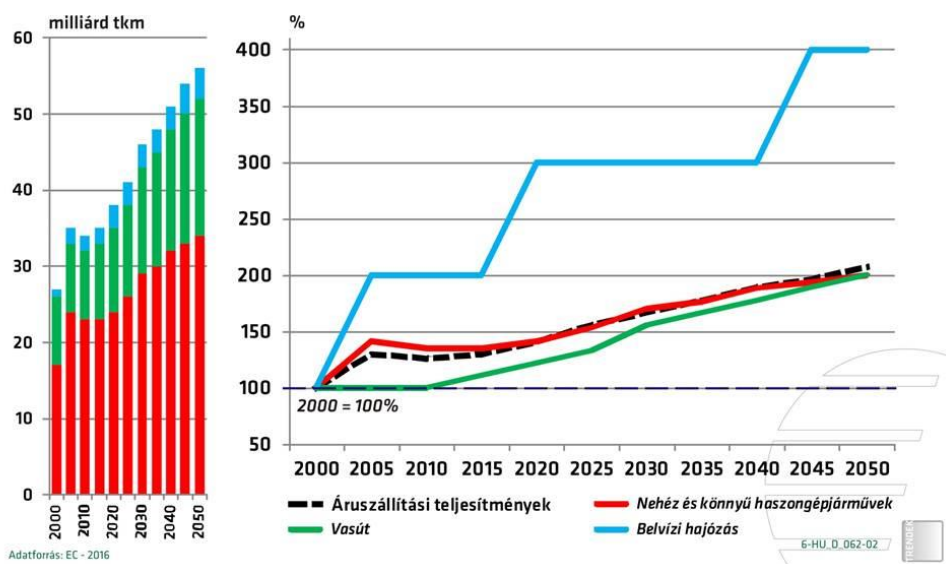

3. számú ábra: Áruszállítási teljesítmények - trendek. ${ }^{11}$

Az ábra alapján az összes ágazat teljesítményét nézve összhangban az európai előrejelzésekkel is azt láthatjuk, hogy a volumenek folyamatosan növekedni fognak, ezáltal a kezelendő mennyiségek nőnek, az ehhez kapcsolódó infrastruktúrának, logisztikai szereplőknek folyamatosan kell fejlődniük és lépést tartaniuk. Minden ágazat és közlekedési mód eltérő problémákkal néz szembe.

A 2014-2020-as CEF projekten belül az alábbi projektek kaptak prioritást.

- Vasúti fejlesztéseket segítő programok keretében megvalósult vasútvonalak átépítése, több útvonal és csomópont meghosszabbítása (reptér), irányítási rendszer korszerűsítés, összekötő vasúti hidak korszerűsítése, vonatbefolyásoló rendszer kiépítése.

- Belvízi áruszállítás fejlesztését segítő programok keretében hidak fejlesztése, dunai hajóút kitűzési rendszer fejlesztése, hajoút

\footnotetext{
${ }^{11}$ KÖZLEKEDÉSTUdOMÁNYI INTÉZET, 2016.
} 
fenntartás, információs rendszer kiépítése, Integrált Kikötői Információs Rendszer kialakítása, kikötők fejlesztése.

- Légi áruszállítás fejlesztését segítő informatikai fejlesztések, kötöttpályás kapcsolatok javítása, kialakítása, légiforgalmi rendszerek fejlesztése.

- Közúti áruszállítás fejlesztését segítő programok keretében több autópálya, gyorsforgalmi út fejlesztése, építése, bővítése, elkerülő szakaszok kiépítése, forgalomirányító rendszerek fejlesztése. ${ }^{12}$

A 2050-ig látható előrejelzés és a CEF által meghatározott célok is abba az irányba mutatnak, hogy a domináns közúti közlekedés mellé a vasúti kapcsolatok felzárkóztatása és intermodálissá tétele fontos szempont, valamint kiemelt terület marad a Duna és a vízi közlekedés fejlesztése, hajózhatósága. Logisztikai szempontból Magyarország közlekedési hálózatának fejlesztéséhez, és ezáltal egy nagyobb logisztikai teljesítmény eléréséhez hazánknak kiemelt figyelmet kell fordítania az egyenlőtlenségek csökkentésére, a további vasúti és belvízi szállitás fejlesztésére, a közutak és átkötő utak komplex fejlesztésére, az áthaladó tranzitútvonalak kialakítására, áruforgalmi kapacitások növelésére, logisztikai központok és szolgáltatók támogatására, eddigi kiemelt kapcsolatok erősítésére (Kína, Oroszország).

\section{A V4-EK REGIONÁLIS EREJE, ÚJ SELYEM-ÚT}

Az Európai közlekedési korridorok és hálózatok valamint az érkező áruszállítási volumenek áttekintése, után, ha globálisan kitekintünk és regionális hálózatokban gondolkodunk, úgy elkerülhetetlen, hogy hatásként ne említsük meg az Európán belüli és kívülről érkező hatásokat, elsősorban a V4 országcsoport és az Új Selyemút kapcsolatát. A Visegrádi Négyek történelme - ez a szoros kötelék, amely létrejött Csehország, Lengyelország, Szlovákia és Magyarország között - évszázadokra nyúlik vissza. Az országok szoros kereskedelmi és diplomáciai együttmúködést hoztak létre, meghatározó szerepet töltenek be Közép- és Kelet-Európa regionális gazdaságában. Regionális együttmúködésüknek természetesen logisztikai vonatkozásai is vannak, amelyek további együttmúködése az országcsoport szerepének növekedését hozhatja. Növekvő beruházási és kereskedelmi áramlás jellemzi, és az új piacok keresése során és eredményeként ezen országok és

12 FLEISCHER, 2007. 
Kína közötti együttmúködés is realizálható. A 2015-ben kiadott öv- és útügyi cselekvési terv szerint a kezdeményezés a szárazföldi útvonalakat („Öv”) és a tengeri útvonalakat („Út”) fogja magában foglalni azzal a céllal, hogy elsősorban infrastrukturális beruházások révén javítsák a régió kereskedelmi kapcsolatait. A V4-ek jelentette összekapcsolhatóság, az új útvonalak kialakításának terve a kereskedőknek és a gyártóknak is több lehetőséget kínál a regionális forgalmazáshoz. Kína célja, hogy fokozza együttműködését Kelet-Európával, beleértve infrastrukturális beruházásokat, technológiai fejlesztésekben való együttműködést, a nemzeti stratégiák függvényében. Logisztikai szempontból alternatívat kínálnak az Ázsia és Nyugat-Európa közötti áruszállításban, amelynek további célja az Európa, Ázsia és Afrika közötti kapcsolatok erősítése. ${ }^{13}$

A 4. számú ábra jól ábrázolja, a projekt nagyságát és alakulását szárazföldön. Az egyik fő út és a korridorok az Eurázsián keresztül húzódó vasúti kapcsolatok, a másik pedig a Délkelet-Ázsia és Afrika felől európai partokhoz érô tengeri szállítmányozási útvonal.

Magyarország volt az elsők között, aki egyetértését fejezte ki a kínai elképzelésekkel és együttműködést írt alá Kínával. A további együttmúködések keretében valósul meg például az a $350 \mathrm{~km}$-es nagysebességű vasút, amely összeköti a magyar fővárosokat és Szerbiát, egyben javítja Magyarország szárazföldi és tengeri összeköttetését; javítják az ország átrakodási csomópont szerepét a régióban, Magyarország ad otthont a Kínai Bank (Bank of China) regionális központjának is. A közlekedési hálózat tekintetében elmondható, hogy bár hazánk nem rendelkezik tengerparttal, de a Duna-menti kikötők fejlesztésével Győr-Gönyü, Budapest, Dunaújváros és Baja városában, amelyek fejlett infrastruktúrával és a Feketetengerhez való hozzáféréssel büszkélkedhetnek, jelentősen növelik Magyarország szerepét az európai vízi közlekedési hálózatban. Erősség továbbá, hogy hazánk Európában a harmadik legnagyobb közúti sűrűséggel rendelkezik. Továbbá budapesti repülőtér bővülése is napirenden van, hogy megfeleljen a megnövekedett igénynek. A vasúti közlekedés területen az ismert Budapest, Belgrád vasútvonal, a Záhonyt a Trieszt-Budapest-KijevMoszkva-Khorgas szállítási folyosót hazánk egyik fő vasúti csomópontjának tekintik. Ezen adottságok mind növelik hazánk szerepét az európai közlekedési folyosók hálózatában. ${ }^{14}$

13 Hong Kong Trade Development Council, 2017.

${ }^{14}$ HKTDC, 2017. 


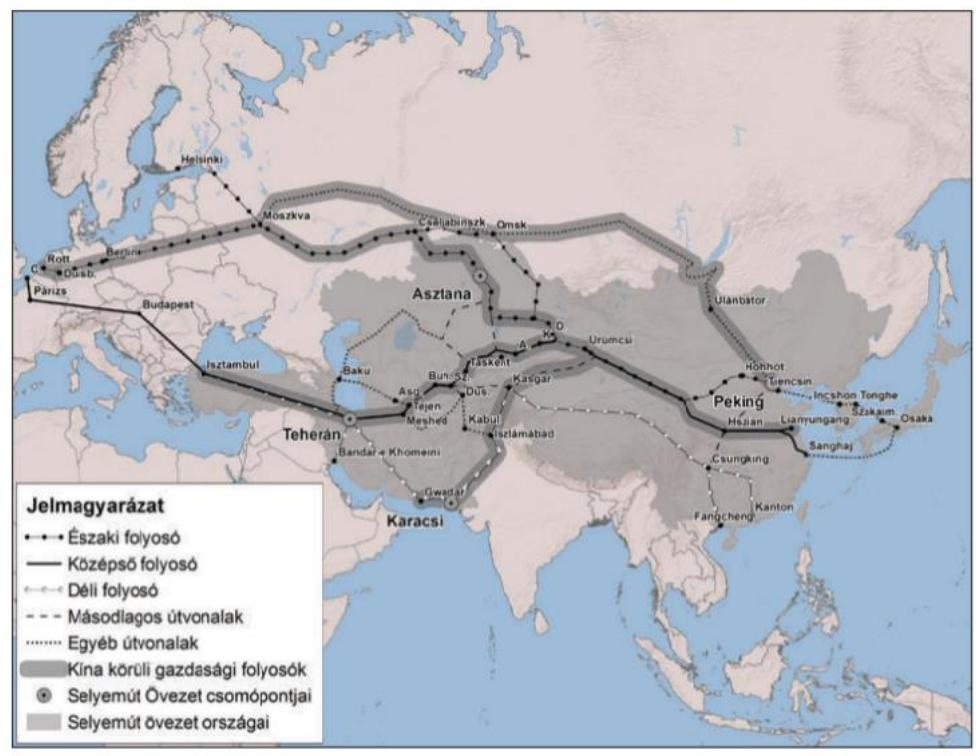

4. számú ábra - Az Új Selyemút. ${ }^{15}$

Ezen szempontok alapján megállapítható, hogy hazánk pozíciója erős, logisztikai szempontból fontos csomópontja lehet ennek a koncepciónak (5. ábra).

Kína és az Új Selyemút a gazdasági és gyártási növekedés mellett a régió további integrációját segítheti elő, elsősorban az ellátási láncokban. Az ebben résztvevők infrastrukturális beruházásaira ösztönző hatással van és lesz. A tengeri útvonalaknál a nagyobb kikötők fejlesztése az Adriai-tenger északi részén és a Fekete-tengeren, valamint összeköttetéseik javítása Európa többi részével kulcsfontosságú szerepet játszik a Gibraltár mentén a fó északi kikötők felé haladó hajók elérésében. A vasúti útvonalak, mint már láthattuk keresztezik továbbá a fő európai vasúti folyosókat Budapesten, Ljubljanában, Salzburgban és Bécsben, lehetővé téve a belépést Közép- és Kelet-Európa piacaira.

15 L JENEY, Á VARGA, 2017. 


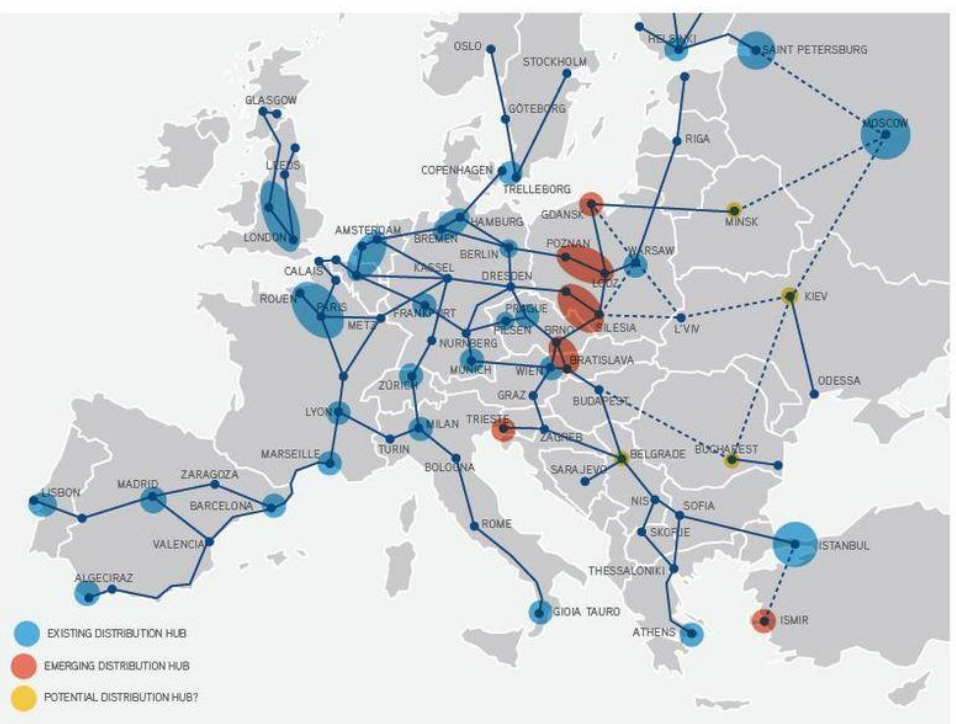

5. számú ábra: Európa várható logisztikai központjai 2020-ban. ${ }^{16}$

\section{KONKLÚZIÓ}

Magyarország és az Európai Unió közlekedési hálózatának fejlesztése egy folyamatos és a jövőben is kiemelt szerepet kapó projekt. Az eddig végrehajtott és a folyamatban levő irányok és elôírások felzárkóztatják Magyarországot és a környező térségeket, új lehetőségeket teremtenek. A hálózat egységesítése és összeköttetéseinek javítása mind élénkítik a gazdaságot. A közlekedési ágazatok fejlesztése nem csak társadalmilag kiemelt jelentőségű, hanem az áruszállításra, logisztikára is kiemelt hatással van.

A fejlesztési projektek a közlekedési hálózat mellett és vele együtt az energia és a távközlési szektort is egységként kezeli, azokat közösen támogatja. Fontos cél az információs rendszerek, infokommunikációs rendszerek fejlesztése, a digitalizáció és a területhez tartozó technológiai felzárkózás és egységesítés. A meglévő és nagy múltra visszatekintő tranzitútvonalak mellett új átkötő és új irányzatok is megjelennek, melyeket a jövőbeli fejlesztéseknél figyelembe kell venni. Véleményem szerint a közlekedéspolitika és a fejlesztések regionális összekapcsolása, elsősorban a

16 STAVEBNÉ FORUM, 2012. 
V4-ek gazdasági súlyának és kapcsolatának erősítése Magyarország számára erősebb és jobb helyzetet teremt, a logisztikai szempontok figyelembevételével is.

Kitekintve az Európai Unió határain és tágabban értelmezve az európai kontinens közlekedési hálózatát, átformáló erőként definiálnám az Új Selyemút koncepciót, amely a várható áruszállítási volumenek növekedésének egyik fő mozgatója. A közlekedési hálózat újragondolása és az új létrejövő útvonalak az áruszállítási volumenek növekedését, Európa és Magyarország áruszállításban betöltött szerepet globálisan erősítik.

\section{FELHASZNÁLT IRODALOM}

European Commission (2013), Directorate General for Mobility and Transport - The Core Network Corridors. Elérhető: https://ec.europa.eu/transport/infrastructure/tentec/tentecportal/site/brochures images/b1 2013 brochure lowres.pdf (Letöltve: 2019. 10. 03.)

European Commission (2014): €11.9 billion to improve European connections. Elérhetô:

https://ec.europa.eu/transport/themes/infrastructure/news/corridors en (Letöltve: 2019. 10. 04.)

European Commission (2015) European Ports Report. [Elérhető: https://ec.europa.eu/transport/sites/transport/files/ static/pdf/infogr aphie-web en.pdf (Letöltve: 2019. 10. 01.)

European Commission, 2015. Trans-European Transport Network.

Elérhető: https://ec.europa.eu/transport/infrastructure/tentec/tentecportal/site/maps upload/SchematicA0 EUcorridor map.pdf (Letöltve: 2019. 10. 01.)

European Commission (2017), Delivering TEN-T report. Elérhető: http://www.connectingeu.eu/documents/Delivering_TEN T.pdf (Letöltve: 2019. 10. 12.)

European Commission (2019), Investing in European networks- Five years supporting European Infrastructure. Elérhető:

https://ec.europa.eu/inea/sites/inea/files/cefpub/cef implementation brochure 2019.pdf (Letöltve: 2019. 10. 04.). DOI azonosító: doi: $10.2840 / 80126$

Fleischer Tamás (2007): Transzeurópai folyosók: A meglévők hosszabbítgatása, vagy egy összeurópai hálózat kialakítása?. In: Glatz 
Ferenc: A Balkán és Magyarország. Európai Intézet Budapest: MTA Társadalomkutató Központ, pp. 365-379.

Hong Kong Trade Development Council (2017): Hungary: Leading the

Way in BRI Co-operation. Elérhető: http://economists-pick-

research.hktdc.com/business-news/article/Research-Articles/Hungary-

Leading-the-Way-in-BRI-Co-

operation/rp/en/1/1X32LK39/1X0AAEGE.htm (Letöltve: 2019. 10.

03.)

Hong Kong Trade Development Council (2017): The Visegrad Four (V4)

Nations: Early Adopters of the Belt and Road Opportunity. Elérhető:

http://economists-pick-research.hktdc.com/business-

news/article/Research-Articles/The-Visegrad-Four-V4-Nations-Early-

Adopters-of-the-Belt-and-Road-

Opportunity/rp/en/1/1X32LK39/1X0AA60I.htm (Letöltve: 2019. 10. 11.)

Jeney László - Varga Ágnes (2017): Az Új Selyemút Övezet gazdaságföldrajza,. In: Budapest: Péti Márton: Az Új Selyemút Gazdasági Övezet geostratégiai és földrajzi dimenziói Budapesti Corvinus Egyetem Gazdaságföldrajz, Geoökonómia és Fenntartható Fejlődés Intézet, 115164.o.

Közlekedéstudományi Intézet (2014) - Trendek és Grafikonok. Elérhető: http://www.kti.hu/index.php?mact=Album,m5,default,1\&m5albumid= 366\&m5page $=2 \& \mathrm{~m} 5$ returnid $=760 \#$ link2 (Letöltve: 2019. 10. 03.)

Közlekedéstudományi Intézet (2016): Magyar áruszállítási teljesítmények.

Elérhető: http://www.kti.hu/trendek/trendek-2050-ig-magyararuszallitasi-teljesitmenyek (Letöltve: 2019. 10. 09.)

Stravebné Forum (2012): The Silk Road of the 21st century. Elérhető: http://www.stavebni-forum.com/en/print/21296/the-silk-road-of-the21st-century/ (Letöltve: 2019. 10. 13.) 